\title{
Thermoelectric Generation and Thermophysical Properties of Metal Oxide Nanofluids
}

\author{
Xinran Hou \\ School of Materials Science and Engineering, Nanchang University, Jiangxi province, China \\ Rong-Tsu Wang \\ Yu Da University of Science and Technology, Miaoli County, 36143, Taiwan, ROC, rtwang@ydu.edu.tw \\ Shaowen Huang \\ School of Materials Science and Engineering, Nanchang University, Jiangxi province, China \\ Jung-Chang Wang \\ Department of Marine Engineering (DME), National Taiwan Ocean University (NTOU), Keelung, 20224, Taiwan, ROC, \\ jcwang@ntou.edu.tw
}

Follow this and additional works at: https://jmstt.ntou.edu.tw/journal

Part of the Fresh Water Studies Commons, Marine Biology Commons, Ocean Engineering Commons, Oceanography Commons, and the Other Oceanography and Atmospheric Sciences and Meteorology Commons

\section{Recommended Citation}

Hou, Xinran; Wang, Rong-Tsu; Huang, Shaowen; and Wang, Jung-Chang (2021) "Thermoelectric Generation and Thermophysical Properties of Metal Oxide Nanofluids," Journal of Marine Science and Technology. Vol. 29: Iss. 1, Article 8.

DOI: $10.51400 / 2709-6998.1007$

Available at: https://jmstt.ntou.edu.tw/journal/vol29/iss1/8

This Research Article is brought to you for free and open access by Journal of Marine Science and Technology. It has been accepted for inclusion in Journal of Marine Science and Technology by an authorized editor of Journal of Marine Science and Technology. 


\title{
RESEARCH ARTICLE
}

\section{Thermoelectric Generation and Thermophysical Properties of Metal Oxide Nanofluids}

\author{
Xinran Hou ${ }^{a}$, Rong-Tsu Wang ${ }^{\mathrm{b}, *}$, Shaowen Huang ${ }^{\mathrm{a}}$, Jung-Chang Wang ${ }^{\mathrm{c}, * *}$ \\ a School of Materials Science and Engineering, Nanchang University, Jiangxi province, China \\ ${ }^{\mathrm{b}}$ Yu Da University of Science and Technology, Miaoli County, 36143, Taiwan, ROC \\ ${ }^{\mathrm{c}}$ Department of Marine Engineering (DME), National Taiwan Ocean University (NTOU), Keelung, 20224, Taiwan, ROC
}

\begin{abstract}
This study describes the comprehensive characterization of the diverse water-based nanofluids involving aluminum oxide, titanium dioxide, and zinc oxide nanoparticles, which were prepared through the two-step synthesis method assisted by a microemulsion ultrasound skill with effects of both weight-percent concentration (wt.\%) in the range of $1.0 \%$ and $5.0 \%$ and between $20{ }^{\circ} \mathrm{C}$ and $40{ }^{\circ} \mathrm{C}$. The mean cluster size, zeta potential, $\mathrm{pH}$ value, viscosity, thermal conductivity, absorbance, light absorption, and electrical charge density of the various nanofluids were surveyed by relative experiments. The results showed that the $2 \mathrm{wt} . \% \mathrm{Al}_{2} \mathrm{O}_{3}, 2 \mathrm{wt} . \% \mathrm{TiO}_{2}$, and $1 \mathrm{wt} . \% \mathrm{ZnO}$ nanofluids were preferentially prepared with a good suspension stability through four weeks. The thermal conductivity and the power generation increased with an increase in temperature. The present synthesis method is suitable for fabricating the metal oxide nanofluids at a temperature between $20{ }^{\circ} \mathrm{C}$ and $40{ }^{\circ} \mathrm{C}$ and a concentration of $1 \mathrm{wt} \%$ to $5 \mathrm{wt} \%$.
\end{abstract}

Keywords: Nanofluid, Two-step Synthesis, Electrochemistry, Redox Reaction

\section{Introduction}

$S$ ince the 20th century, after the launch of the suspending nanopowders within a liquid, nano liquid research has marked nanotechnology as the modern skill with broad applications in diagnosis, sensing, and therapeutic medicine, agriculture, textiles, and energy, etc [1-5]. The nanofluid has various striking features such as the capacity to enhance thermal, magnetic, and electric performances of the base fluid. In recent times, metal oxide nanoparticles blended with base fluids have received much attention as the most promising alternatives to the existing working fluids [6-11]. Metal oxide nanofluids of suspended homogeneous metal oxide nanoparticles possess good thermal performance but poor suspension and stability, restricting its use, because of a strong size effect against thermal conductivity and fluid behavior. Manipulation of hydrodynamics, stochastic, electrostatic, and Van Der Waals' forces altered the surface area of the nanoparticles and the collision frequency, which change the boiling heat transfer, thermal conductivity, and suspendability of the nanofluids. The major factors dominating the suspension and stability of the nanofluids are the particle size and geometry, concentration, surface obstruction, solution chemistry, and cohesion situation of nanoparticles within the nanofluids [12, 13].

The present study blended metal oxide nanoparticles directly into the aqueous solution to prepare the metal oxide nanofluids known as the immediate two-step synthesis method, which lead to nanoparticle clumping and reducing 
suspendability of nanofluids. The convenience of the immediate two-step synthesis method was that the granularity and concentration of the metal oxide nanofluid could be better governed based on the usages [14]. Some significant factors for assessing the suspendability of nanofluid include visual examination, $\mathrm{pH}$ value, zeta potential, and particle size distribution apparatus. Three following methods were employed to stabilize the suspended metal oxide nanoparticles in this study, wherein the $\mathrm{pH}$ value of the metal oxide nanofluid was transformed far away the isoelectric point (IEP) to avoid sedimentation, an ultrasonicator was utilized to disperse the nanoparticles, and a surfactant/dispersant was blended to elevate dispersion and suspension [15, 16]. The present study also adopted an emulsifying agent to improve the suspendability of the nanoparticles in the metal oxide nanofluid based on past studies [17-19]. Wang and Wang [17, 19] found that higher concentrations of the emulsifying agent decreased the zeta potential of the suspended nanoparticles and the thermal conductivity of the nanofluid. They obtained the best concentrations of aluminium oxide $\left(\mathrm{Al}_{2} \mathrm{O}_{3}\right)$ nanopowder, emulsifying agent, and dispersant operating at fixed $2 \mathrm{wt} \%$ and temperature between $25{ }^{\circ} \mathrm{C}$ and $40{ }^{\circ} \mathrm{C}$. The nanofluids displayed higher thermal conductivity compared to the base fluid, and an increase in thermal conductivity with an increase in temperature. The nanoparticles enhanced the heat transfer rate even at a small volume fraction [20-24].

Gan et al. [25] observed that the thermal conductivity of $\mathrm{TiO}_{2}$ nanofluid increases by $7.28 \%$ when it was prepared under optimum conditions, and this titanium dioxide $\left(\mathrm{TiO}_{2}\right)$ nanofluid with the optimum thermal conductivity was used as the working fluid. Nadooshan [26] prepared and evaluated the thermal conductivity of zinc oxide $(\mathrm{ZnO})$ nanofluid by a twostep method and a hot-wire skill pro instrument. The results revealed that the thermal conductivity of $\mathrm{ZnO}$ nanofluids significantly increases with increasing solid volume fraction at higher temperatures. Eventually, the present research investigated the thermophysical properties and thermoelectric generations of metal oxide nanofluids as working fluids and electrolytes, respectively, containing $\mathrm{Al}_{2} \mathrm{O}_{3}, \mathrm{TiO}_{2}$, and $\mathrm{ZnO}$ nanoparticles blending aqueous solution. A microemulsion ultrasonic technique was utilized to prepare the metal oxide nanofluid. Wang et al. [27-30] exploited the $\mathrm{Al}_{2} \mathrm{O}_{3}$ nanofluid as an electrolyte compared with the other aqueous solutions based on the $\mathrm{pH}$ value, Zeta potential, viscosity, and thermal conductivity to indicate the most favorable stability, thermal conductivity, particle fraction, and stable current output. The present study intended to develop a suitable synthesis method for fabricating the metal oxide nanofluids at a temperature between $20{ }^{\circ} \mathrm{C}$ and $40{ }^{\circ} \mathrm{C}$ and a concentration of $1 \mathrm{wt} . \%$ to $5 \mathrm{wt} . \%$.

\section{Methodology}

The nanofluids were prepared through the twostage synthesis, via the measurement of different nanofluids' thermoelectric properties, and the derivation of their empirical formulas. The nanoparticles and deionized water (DW) were proportioned and added into the interface agent to increase the suspension stability of the nanofluids, and the nanoparticle was dispersed in the solution with ultrasonic vibration technology. The condition of the nanofluid at different times and concentrations was detected by the instrument, and the empirical formulas of thermoelectric performance were derived through the intelligent dimensional analysis of the experimental data.

\section{Nanofluid preparation}

The current investigation employed three kinds of nanoparticles including aluminum oxide, titanium dioxide, and zinc oxide. The densities and mean radii of the individual $\mathrm{Al}_{2} \mathrm{O}_{3}$ (Yong-Zhen Technomaterial Co., Taiwan), $\mathrm{TiO}_{2}$ (Evonik Degussa Co., Taiwan), and $\mathrm{ZnO}$ (Sigma-Aldrich Co., Taiwan) nanoparticles were respectively $3.97 \mathrm{~g} / \mathrm{cm}^{3}$ and $12 \mathrm{~nm}, 3.90 \mathrm{~g} / \mathrm{cm}^{3}$ and $21 \mathrm{~nm}$, and $5.50 \mathrm{~g} / \mathrm{cm}^{3}$ and $20 \mathrm{~nm}$. The specific surface areas of $\mathrm{Al}_{2} \mathrm{O}_{3}$ and $\mathrm{ZnO}$ were greater than or equal to $100 \mathrm{~m}^{2} / \mathrm{g}$, and $50 \mathrm{~m}^{2} / \mathrm{g}$, respectively. The specific surface area of $\mathrm{TiO}_{2}$ was $50 \pm 15 \mathrm{~m}^{2} / \mathrm{g}$. Furthermore, the thermal conductivities and specific heats of the $\mathrm{Al}_{2} \mathrm{O}_{3}, \mathrm{TiO}_{2}$, and $\mathrm{ZnO}$ nanoparticles were approximately $38 \mathrm{~W} /(\mathrm{m} \cdot \mathrm{K})$ and $0.78 \mathrm{~kJ} /(\mathrm{kg} \cdot \mathrm{K}), 12 \mathrm{~W} /(\mathrm{m} \cdot \mathrm{K})$ and $0.52 \mathrm{~kJ} /(\mathrm{kg} \cdot \mathrm{K})$, and $21 \mathrm{~W} /(\mathrm{m} \cdot \mathrm{K})$ and $0.49 \mathrm{~kJ} /(\mathrm{kg} \cdot \mathrm{K})$, respectively. The SEM (Scanning Electron Microscope) images of the prepared nanoparticles are demonstrated in Fig. 1.

Fig. 2 presents the manufacturing process of these three nanofluids with different weight percent concentrations ranging from $1.0 \mathrm{wt} . \%$ to $5.0 \mathrm{wt} . \%$. A water-soluble dispersant labeled QF-DTK-190 (Yong-Zhen Technomaterial Co., Taiwan) was used for dispersing the $\mathrm{Al}_{2} \mathrm{O}_{3}, \mathrm{TiO}_{2}$, and $\mathrm{ZnO}$ nanoparticles uniformly in the de-ionized water (DW) and its density, thermal conductivity, and $\mathrm{pH}$ value were approximately $1.0 \mathrm{~g} / \mathrm{cm}^{3}, 0.52 \mathrm{~W} /(\mathrm{m} \cdot \mathrm{K})$, and 6.5 , respectively. The concentrations of the interface active agents and the oscillatory time of supersonic waves influenced the suspended stability and the powder sizes of $\mathrm{Al}_{2} \mathrm{O}_{3}, \mathrm{TiO}_{2}$, and $\mathrm{ZnO}$ nanofluids. 


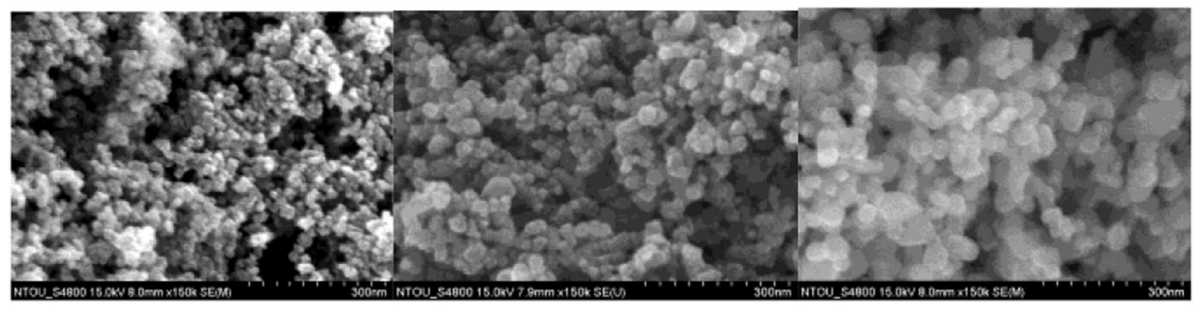

(a) $\mathrm{Al}_{2} \mathrm{O}_{3}$

(b) $\mathrm{TiO}_{2}$

(c) $\mathrm{ZnO}$

Fig. 1. SEM images of nanoparticles.

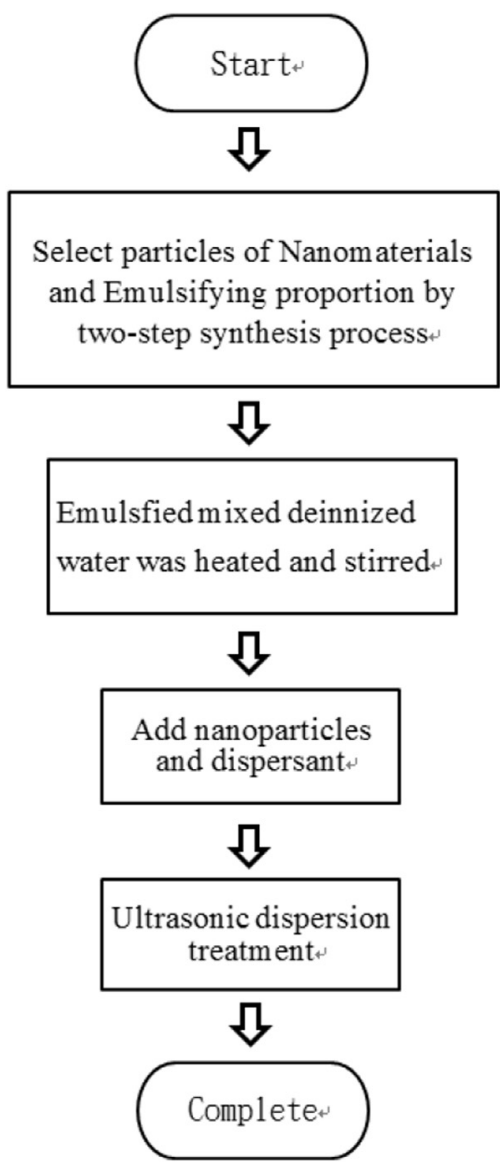

Fig. 2. Nanofluids preparation procedure.

The emulsifying agent containing the non-ionic surfactants Tween\#20, Tween\#80, Span\#20, and Span\#80 all from First Chemical Co., Taiwan were incorporated to enhance the suspension stability of the nanofluids using ultrasonic vibration. Tween\#80 $(\mathrm{HLB}=15)$ and Span\#20 $(\mathrm{HLB}=8.6)$ were mixed and stirred at $400 \mathrm{rpm}$ for $60 \mathrm{~min}$ into an HLB $=12$ emulsifying agent and its density and thermal conductivity were approximately $1.05 \mathrm{~g} / \mathrm{cm}^{3}$ and $0.175 \mathrm{~W} /(\mathrm{m} \cdot \mathrm{K})$, respectively.

Four experimental preparation instruments were used. An analytical balance (Shimadzu Co., Japan) with a maximum measurement value of $220 \mathrm{~g}$ and the lowest precision of $10^{-4} \mathrm{~g}$ was adopted to gauge the slight weight of nanoparticles and interface active agent. An electromagnetic hot plate with a stirrer named PC-620D (Corning Co., USA) was employed for stirring the nanofluids between 60 and $1150 \mathrm{rpm}$ at a maximum heating temperature of $550{ }^{\circ} \mathrm{C}$. The emulsifying agent $(\mathrm{HLB}=12$ ) and deionized water were heated and mixed by stirring at $80{ }^{\circ} \mathrm{C}$ and $500 \mathrm{rpm}$ for approximately $50 \mathrm{~min}$. The samples were cooled naturally or by using a constant temperature bath at $25^{\circ} \mathrm{C}$. A circulating water bath (He-Yu Technology Co., Taiwan) with a heating power of $1 \mathrm{~kW}$, a frozen force of $1 / 3 \mathrm{HP}$, a volume capacity of $20 \mathrm{~L}$, and the operating temperature between -20 and $100{ }^{\circ} \mathrm{C}$ was employed at a constant temperature to preserve the temperature of the nanofluids. A supersonic homogenizer of ultrasonic 250 model (He-Yu Technology Co., Taiwan) was used to prepare the various $\mathrm{Al}_{2} \mathrm{O}_{3}, \mathrm{TiO}_{2}$, and $\mathrm{ZnO}$ nanoparticle concentrations of the nanofluids. The maximum power, supersonic frequency, and processing capacity of the ultrasonic 250 model applied were $250 \mathrm{~W}, 23 \mathrm{kHz}$, and $0.2-400 \mathrm{~mL}$, respectively. These nanofluids were cooled to continue oscillation at a total oscillation time of approximately $60 \mathrm{~min}$ $[17,18]$. The thermal conductivities and power densities of the various $\mathrm{Al}_{2} \mathrm{O}_{3}, \mathrm{TiO}_{2}$, and $\mathrm{ZnO}$ nanofluids with different concentrations were analyzed, and changes were observed after resting. Afterward, the intelligent dimensional analysis was used to derive an empirical formula using the experimental data.

\section{Nanofluid property test}

These nanofluids testing instruments are shown in Fig. 3. Six thermal performances were assessed to measure and acquire for the suspendability and stability of these nanofluids with different concentrations including the grain size, thermal conductivity, zeta potential, $\mathrm{pH}$ value, viscosity, and absorbance. Besides, the micro-power generation 


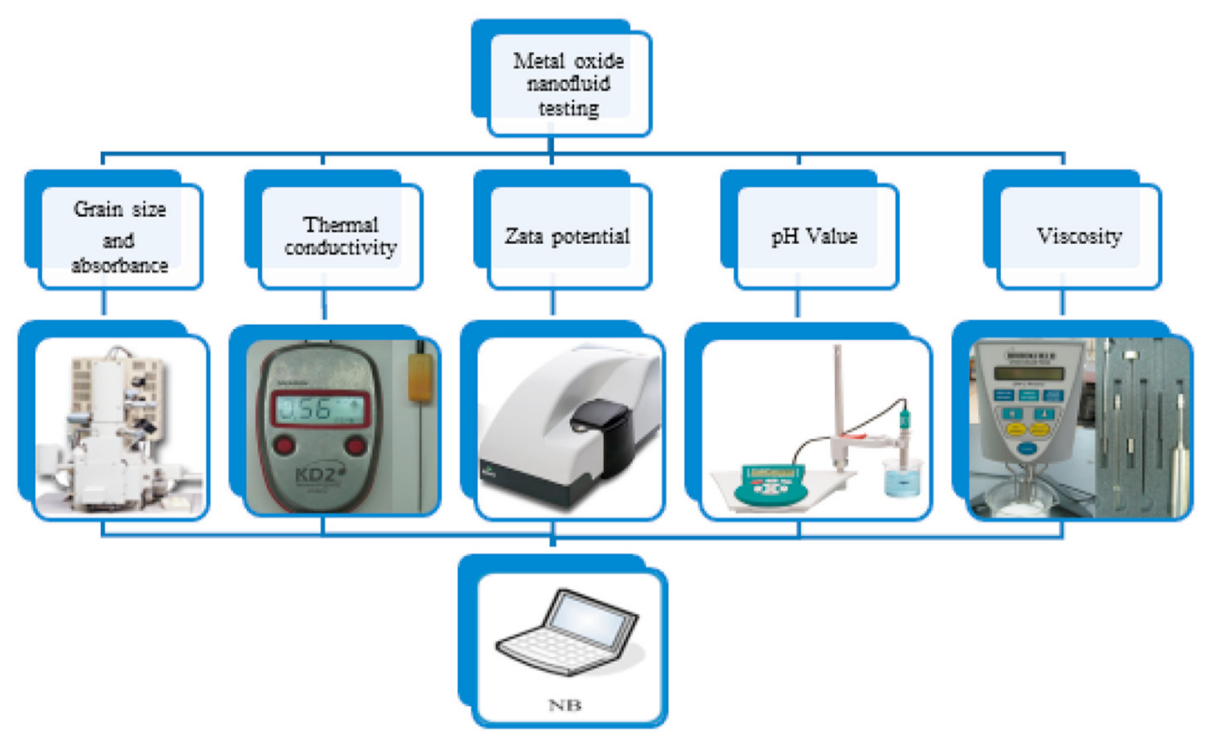

Fig. 3. Instruments used to test nanofluids.

characteristics in power generation facility of reduction-oxidation reaction were explored by the electrical performance detection of the metal oxide nanofluids as electrolytes to discuss the electrical properties involving the output current and the electric density. The detection steps for testing each thermoelectric property are discussed henceforth.

The suspendability and stability of the metal oxide nanoparticles within the nanofluid was based on the mean grain size. The grain size and zeta potential analyzer (Malvern Co., Switzerland) was used to observed the mean grain size of metal oxide powders to determine the influence of varying concentrations and oscillation times on grain size. The particle size analyzer was turned on waiting for 5 min to warm-up and connect to the software instrument. The electrode pad of the surface potential specific colorimetric tank was checked. Next, the sample was kept into the specific colorimetric tank without bubbles and then set in the analyzer for measuring the particle size and zeta potential of metal oxide nanofluids. A portable thermal conductivity meter, KD2 (Decagon Devices Inc., USA) was adopted to survey the thermal conductivity coefficients of metal oxide nanofluids. The probe was immersed completely into the nanoliquid and left as such for $2 \mathrm{~min}$ to record the stable data. The operating environment of KD2 was -20 to $60^{\circ} \mathrm{C}$ and its measuring range of thermal conductivity was $0.02-2 \mathrm{~W} /(\mathrm{m} \cdot \mathrm{K})$ with an accuracy of $\pm 2.5 \%$. The main principle of KD2 is based on the transient hot- wire theory derived from one-dimensional Fourier's law as mentioned in equation (1).

$K=\frac{Q}{A \cdot\left(T_{2}-T_{1}\right)} \cdot\left(\frac{\tau_{2}}{\tau_{1}}\right)$

where $\mathrm{K}$ is the thermal conductivity, $\mathrm{Q}$ is the heat flow, $\mathrm{A}$ is the area, $\mathrm{T}$ is the temperature, and $\tau$ is the time. When $\tau$ equals zero, thermal equilibrium is achieved. The time changes from $\tau_{1}$ to $\tau_{2} \mathrm{t} 2$ and temperature changes from $T_{1}$ to $T_{2}$ as given one unit of the $\mathrm{Q}$. During this thermodynamic process, the temperature increases or decreases after dominating to changes with thermal energy. Finally, the thermal conductivity $\mathrm{K}$ of metal oxide nanofluids can be estimated.

The zeta potential alters along with acid and alkali $(\mathrm{pH})$ value and isoelectric points (IEPs), which is a critical factor for deciding the suspendability and stability of the metal oxide powders within the nanofluids. Scilicet zeta potential with the $\mathrm{pH}$ value of the metal oxide nanofluid was examined to confirm the presence of sufficient electrostatic repulsion between the metal oxide nanoparticles. The desktop $\mathrm{pH}$ meter (Metrohm company of Switzerland) was used to measure the $\mathrm{pH}$ value of nanofluids with different concentrations of surfactants and metal oxide nanoparticles, which could be compared with the surface potential to avoid the IEP of metal oxide nanofluids. Briefly, the $\mathrm{pH}$ meter was started and the initial value was adjusted by using 
the calibration solutions at $\mathrm{pH} 3,7$, and 9. The probe was then rinsed with deionized water and dried carefully with a dry tissue. The probe was then placed in the solution and the instrument test was allowed to finish. The zeta potential of metal oxide nanofluids at an IEP has zero value. A spectrophotometer U-1900 (Hitachi Inc., Japan) was used to measure the absorbance of the metal oxide nanofluids at different weight concentrations and preservation times. The light absorbance was defined as the portion of light energy absorbed on the passage of light source through the metal oxide nanofluids. The absorbance value can judge the suspension property of the metal oxide nanofluids. The range of wavelength measurement by the U-1900 was between $190 \mathrm{~nm}$ and $1100 \mathrm{~nm}$ with a bandwidth of $1.5 \mathrm{~nm}$ and an error range of $\pm 0.5 \mathrm{~nm}$.

The viscosity of the fluid is also closely related to the suspension and stability and is a crucial factor for the thermoelectric performance of metal oxide nanofluids. High-viscosity fluids affect the Brownian movement of the metal oxide nanopowders in the liquid and easily cause aggregation and precipitation. Therefore, the viscosity of each metal oxide nanofluid was measured using a capillary viscosity meter, K698 (Cannon Inc., USA) based on the ASTM D445 standard test for the kinematic viscosity of transparent and opaque liquids, which has a repeatability of $0.11 \%$ in most situations. A rotor of K698 was selected for measuring low viscosity fluids, and the test solution was poured in a water tube at a constant temperature of $40{ }^{\circ} \mathrm{C} \pm 0.02{ }^{\circ} \mathrm{C}$, at appropriately set rotation speed. The deviation of K698 was less than $\pm 3 \%$. Thermoelectric properties of the metal oxide nanofluids were measured by the battery framework as shown in Fig. 4. The battery tank was assessed for currents, voltages, and power outputs in different metal oxide solutions as the electrolytes in a battery cell through redox reactions exploited with red brass (cathode) and aluminum (anode) electrodes at different concentrations under distinct temperatures. Each electrode under the

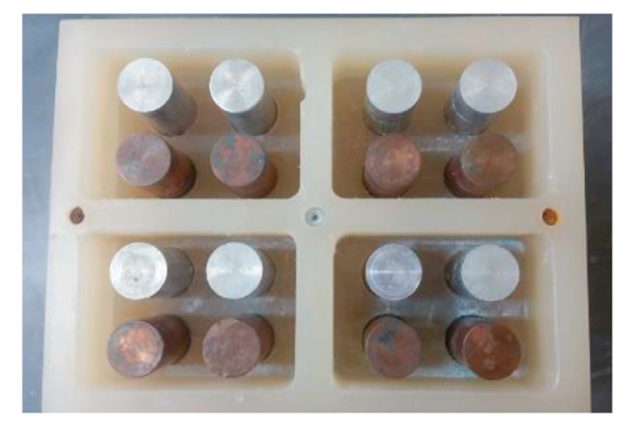

Fig. 4. Battery framework. liquid surface has a surface area of about $1151.5 \mathrm{~mm}^{2}$ for a reaction. These electrodes have a diameter of $17.8 \mathrm{~mm}$ and a length of $68 \mathrm{~mm}$. The dimension of the battery tank is $69.9 \mathrm{~mm} \times 48.8 \mathrm{~mm}$ $x 30.3 \mathrm{~mm}$. The electrolyte fixed at $50 \mathrm{~mL}$ was added into the battery tank. The electric charge density was adopted to appraise the power generation capacity of the metal oxide water-based nanofluids, which was calculated by the value of electric quantity divided by the electrode reaction area.

\section{Results and discussion}

The present study explored the suspensibility and stability of deionized water (DW) as a solvent with the addition of emulsifier and dispersant into the metal oxide nanofluids and discussed the impacts of surfactant and ultrasonic oscillating time on the metal oxide nanofluids at varying concentrations of the solution. The detection range of the metal oxide nanofluids was as per earlier publications [17, 18]. The nanofluids precipitate particles in the static environment with time. Quantifications of mean grain size, $\mathrm{pH}$ value, density, zeta potential, viscosity, and absorbance were utilized to define the stability, suspensibility, and the better concentration of the metal oxide nanofluids. The concentrations of the metal oxide nanofluids were in the range of 1.0-5.0 wt. \%. The experimental findings were employed in intelligent dimensional analysis to obtain the empirical formulas, which took into account the emulsifying agents.

To improve the suspension stability of the metal oxide nanofluids, the emulsifying agent $(\mathrm{HLB}=12)$ and dispersant were blended with nanofluids for expanding the thickness of the double dielectric layer and decreasing the surface tension on the surface of metal oxide nanoparticles. Fig. 5 exhibits the average size of metal oxide nanofluids with or without surfactant. Two layers comprising an emulsified bed and a sediment bed were observed in the metal oxide nanofluid after it was kept stable and motionless for a specific period. The mean grain size of nanofluid without surfactant increased and precipitated after one week of being motionless. Inversely, the metal oxide nanofluids with the surfactant suspended for a longer duration of 28 days above. Fig. 5(a) displayed that the titanium dioxide $\left(\mathrm{TiO}_{2}\right)$ nanofluid without surfactant added had obvious particle agglomeration after seven days. The mean size of the $\mathrm{TiO}_{2}$ nanoparticles increased from $47 \mathrm{~nm}$ to $556 \mathrm{~nm}$. However, the particle agglomeration phenomenon of the nanofluid with 2 wt.\% surfactant added was relatively small from $53 \mathrm{~nm}$ to $78 \mathrm{~nm}$ within 35 days. Fig. 5(b) shows that 


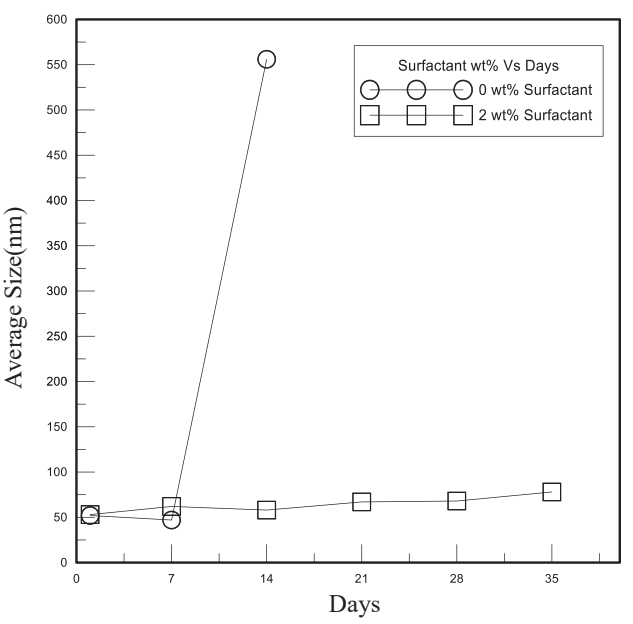

(a) $\mathrm{TiO}_{2}$

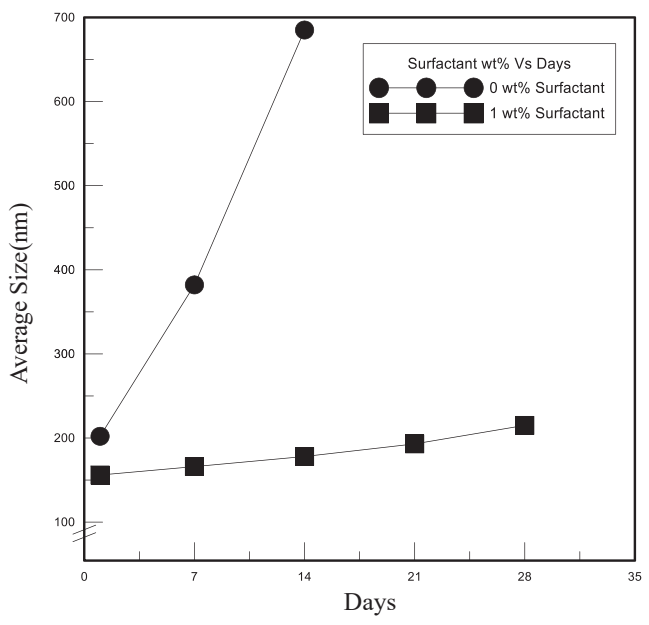

(b) $\mathrm{ZnO}$

Fig. 5. Nanofluids with or without surfactant.

the $\mathrm{ZnO}$ nanofluid without added surfactant had significant particle agglomeration because the density of $\mathrm{ZnO}$ is larger than that of $\mathrm{TiO}_{2}$. The mean size of $\mathrm{ZnO}$ nanoparticles increased from $202 \mathrm{~nm}$ to $685 \mathrm{~nm}$. However, the particle agglomeration phenomenon of the nanofluid containing $1 \mathrm{wt} \%$ surfactant was relatively small from $156 \mathrm{~nm}$ to $215 \mathrm{~nm}$ within 28 days. Most of the heavier and clustered metal oxide nanoparticles without surfactant effects precipitated and agglomerated to the bottom due to gravity.

In the present study, the ultrasonic microemulsification technology was used to force the dispersion of nanoparticles after coating by emulsification, which was a transient phenomenon. The oscillation time required to prepare nanofluid can be observed through the size of the nanoparticles, which affects the suspension of the nanoparticles and determines the effects of different metal oxide nanofluids and ultrasonic oscillation time on the nanoparticles size. In the $\mathrm{TiO}_{2}$ nanofluid shock time experiment, the mean grain size of the nanoparticles was $330 \mathrm{~nm}$ after only magnetic stirring. Nevertheless, the mean grain size of the nanoparticles was $72 \mathrm{~nm}$ and $57 \mathrm{~nm}$ after the ultrasonic shock of $30 \mathrm{~min}$ and $60 \mathrm{~min}$, respectively. Further, the mean grain sizes of the nanoparticles were $55 \mathrm{~nm}$ and $50 \mathrm{~nm}$ after $90 \mathrm{~min}$ and $120 \mathrm{~min}$, respectively. Fig. 6(a) shows that the $\mathrm{TiO}_{2}$ nanofluid had better nanoparticle size after $60 \mathrm{~min}$ of oscillation time. In

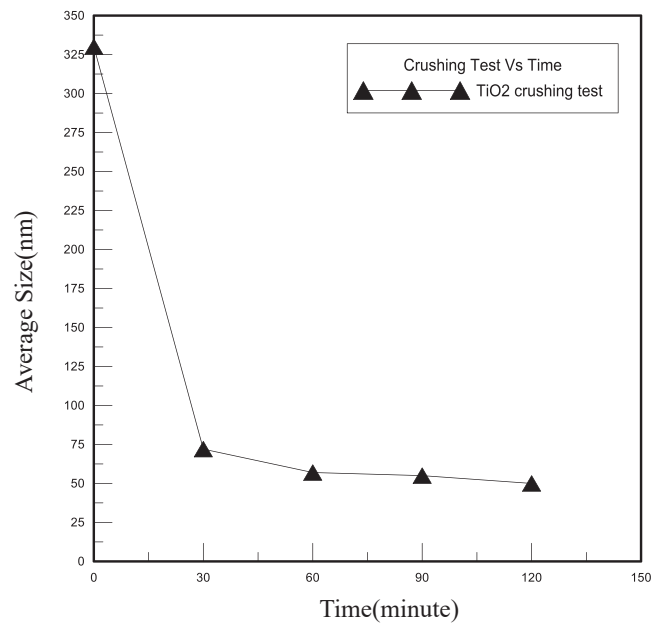

(a) $\mathrm{TiO}_{2}$

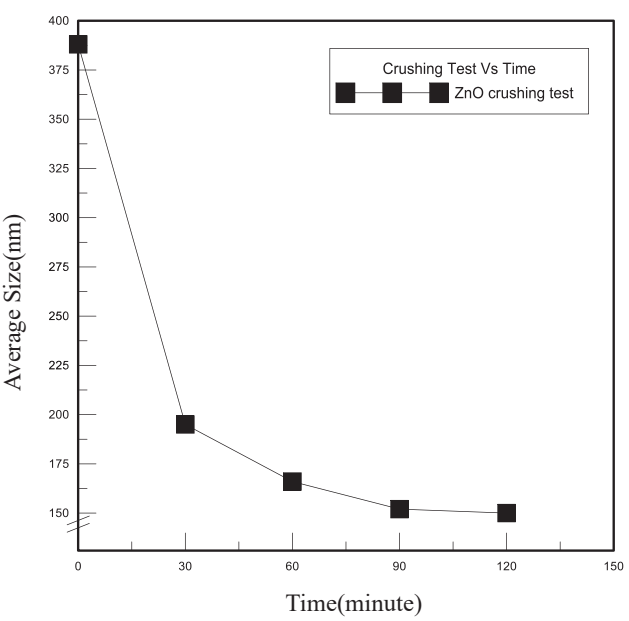

(b) $\mathrm{ZnO}$

Fig. 6. Crushing time of ultrasonic action for metal oxide nanoparticles. 
Table 1. Changes in metal oxide nanoparticle grain size for four weeks.

\begin{tabular}{lllllll}
\hline \multicolumn{7}{l}{ Mean grain size of nanofluid (nm) } \\
\hline wt.\% & & 1.0 & 2.0 & 3.0 & 4.0 & 5.0 \\
Day & & & & & & \\
\hline $\mathrm{Al}_{2} \mathrm{O}_{3}$ nanofluids & 1 & 155.2 & 168.9 & 198.1 & 202.6 & 206.1 \\
& 7 & 159.2 & 170.1 & 200.6 & 206.8 & 210.4 \\
& 14 & 186.5 & 167.1 & 210.1 & 209.3 & 218.8 \\
& 21 & 188.6 & 175.9 & 211.9 & 215.6 & 223.5 \\
& 28 & 192.5 & 185.3 & 213.2 & 223.8 & 230.2 \\
$\mathrm{TiO}_{2}$ nanofluids & 1 & 65 & 48 & 50 & 40 & 42 \\
& 7 & 73 & 50 & 55 & 43 & 48 \\
& 14 & 78 & 56 & 58 & 50 & 49 \\
& 21 & 83 & 60 & 64 & 48 & 52 \\
& 28 & 92 & 67 & 68 & 55 & 56 \\
$\mathrm{ZnO}$ nanofluids & 1 & 156 & 162 & 167 & 171 & 177 \\
& 7 & 166 & 172 & 173 & 182 & 192 \\
& 14 & 178 & 185 & 183 & 199 & 208 \\
& 21 & 193 & 197 & 201 & 206 & 228 \\
& 28 & 215 & 221 & 226 & 227 & 244 \\
\hline
\end{tabular}

the $\mathrm{ZnO}$ nanofluid shaking time experiment, the mean grain size of the nanoparticles was $388 \mathrm{~nm}$ after magnetic stirring. After ultrasonic vibration, the mean grain sizes were $195 \mathrm{~nm}, 166 \mathrm{~nm}, 152 \mathrm{~nm}$, and $150 \mathrm{~nm}$, after $30 \mathrm{~min}, 60 \mathrm{~min}, 90 \mathrm{~min}$, and $120 \mathrm{~min}$, respectively. The mean grain size of the $\mathrm{ZnO}$ nanoparticles had a tendency to shrink with the increase in the shaking time, however, the amplitude of shrinkage at $90-120$ min shaking time was not significant as shown in Fig. 6(b).

Table 1 lists the mean grain diameter of the metal oxide nanoparticles used in the present study at rest for four weeks. After keeping still for seven days, the mean grain size increased only slightly and no precipitation happened. For the $\mathrm{Al}_{2} \mathrm{O}_{3}$ nanofluid, the discriminations in mean grain size for the other specimen were minor except that the $1 \mathrm{wt} \%$ specimen for which the mean grain size increased nearly $30 \mathrm{~nm}$ at two weeks. However, the best concentration of the $\mathrm{Al}_{2} \mathrm{O}_{3}$ was the $2 \mathrm{wt} . \%$. The nanoparticle sizes of $\mathrm{TiO}_{2}$ nanofluid reduced with an increase in concentration because of the isoelectric point (IEP). The surface potential of the $1 \mathrm{wt} . \% \mathrm{TiO}_{2}$ nanofluid was insufficient to cause nanoparticle agglomeration, and its mean grain size increased by $27 \mathrm{~nm}$ compared with those at other concentrations over 1-28 days. The mean grain size of the $\mathrm{ZnO}$ nanofluid increased with increasing concentration. From 1 to 28 days, the surface potential of $5 \mathrm{wt} . \% \mathrm{ZnO}$ nanofluid was closer to the IEP so that the agglomeration was more acute with a total increase in sizes of $64 \mathrm{~nm}$. The above outcomes signify a quicker precipitation rate of the metal oxide nanoparticles after staying motionless for a long term or centrifuged for metal oxide nanofluids. In fact, the mean grain size cannot exactly depict the precipitation of the metal oxide nanofluids. Intrinsically, observations with the naked eye and absorbance measurements had to be done in a supplement to decide the best suspendability and stability of the metal oxide nanofluids $[17,18]$.

The surface potential of the metal oxide nanofluids is in effect, the strength of mutual repulsion between these nanoparticles. The metal oxide nanofluids had an IEP at a specific $\mathrm{pH}$, therefore, the surface potential of the metal oxide nanofluids at the IEP was zero resulting in the agglomeration and causing precipitation. The $\mathrm{pH}$ value and surface potential of the metal oxide nanofluids were detected regularly by the instrument to avoid approaching the IEP. In other words, the farther the $\mathrm{pH}$ value of the metal oxide nanofluids was from the IEP, the more net charge, at a faster electrophoresis speed, and the converse at a slower speed. Consequently, an appropriate $\mathrm{pH}$ value for preparing the metal oxide nanofluids should be selected to ensure a large difference in the charge of the nanoparticles, which is more conducive to the separation from each other. The zeta potential of the metal oxide nanofluids changed along with the weight concentrations in the present study and adding an emulsifying agent $(\mathrm{pH}=6.5)$ decreased the zeta potential. The $2 \mathrm{wt} . \% \mathrm{Al}_{2} \mathrm{O}_{3}$ nanofluids at $\mathrm{pH} 5.18$ had rather well suspension stability $[17,18]$. Fig. 7 (a) displays that the IEP of the $\mathrm{TiO}_{2}$ nanofluids was nearly at $\mathrm{pH}$ 7.3. The $\mathrm{pH}$ value and surface potential of the $\mathrm{TiO}_{2}$ nanofluids between $1.0 \mathrm{wt} \%$ and 5.0 wt. $\%$ decreased with concentration, in a downward trend. The $\mathrm{pH}$ value of the $1.0 \mathrm{wt} \% \mathrm{TiO}_{2}$ nanofluids was closer to their IEP so that the surface potential was insufficient resulting in more obvious agglomeration. The IEP of the $\mathrm{ZnO}$ nanofluids was around a $\mathrm{pH}$ of 9.2 as shown in Fig. 7(b). The $\mathrm{pH}$ value of the $5.0 \mathrm{wt} . \% \mathrm{ZnO}$ nanofluids demonstrated significant precipitation. This was because the emulsion layer became thicker with reduced zeta potential due to the increase in emulsifier concentration. The $\mathrm{pH}$ values for the metal oxide nanofluids employed in the present study did not come closer to their IEPs.

Table 2 reveals that the thermal conductivity of the metal oxide fluids may not raise with the increase in the concentrations of the emulsifying agent. However, the thermal conductivities for the metal oxide nanofluids raised with an increase in temperature. This may be because the thermal conductivity of the emulsifying agent was $0.15 \mathrm{~W} /$ $(\mathrm{m} \cdot \mathrm{K})$; while the emulsifying agent can overcover the metal oxide nanoparticles causing an increase in their surface tension so that they do not aggregate without affecting the thermal conductivity. 


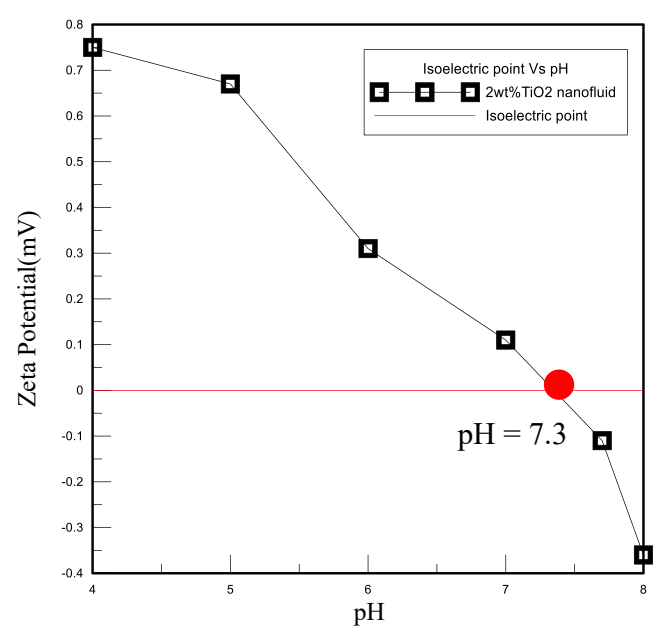

(a) $\mathrm{TiO}_{2}$

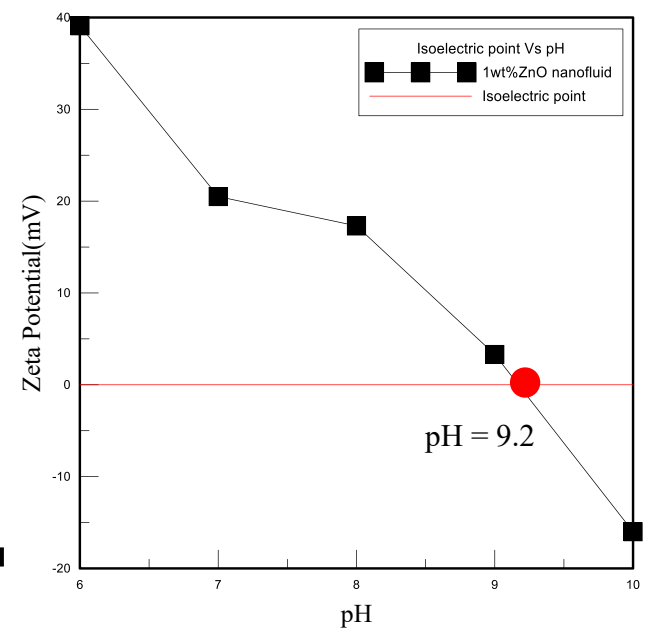

(b) ZnO

Fig. 7. IEP of the metal oxide nanofluids.

Table 2. Metal Oxide nanofluids thermal conductivities $W /(m \cdot K)$.

\begin{tabular}{lllllll}
\hline $\begin{array}{l}\text { wt. } \% \\
\text { Temp. }\end{array}$ & & 1.0 & 2.0 & 3.0 & 4.0 & 5.0 \\
\hline $\mathrm{Al}_{2} \mathrm{O}_{3}$ nanofluids & $20{ }^{\circ} \mathrm{C}$ & 0.61 & 0.58 & 0.57 & 0.57 & 0.56 \\
& $25{ }^{\circ} \mathrm{C}$ & 0.62 & 0.60 & 0.57 & 0.58 & 0.57 \\
& $30{ }^{\circ} \mathrm{C}$ & 0.63 & 0.61 & 0.58 & 0.58 & 0.58 \\
& $35{ }^{\circ} \mathrm{C}$ & 0.64 & 0.61 & 0.60 & 0.59 & 0.59 \\
& $40{ }^{\circ} \mathrm{C}$ & 0.64 & 0.63 & 0.61 & 0.61 & 0.60 \\
$\mathrm{TiO}_{2}$ nanofluids & $20^{\circ} \mathrm{C}$ & 0.59 & 0.59 & 0.57 & 0.56 & 0.56 \\
& $25{ }^{\circ} \mathrm{C}$ & 0.61 & 0.62 & 0.58 & 0.57 & 0.56 \\
& $30^{\circ} \mathrm{C}$ & 0.62 & 0.63 & 0.62 & 0.60 & 0.58 \\
& $35^{\circ} \mathrm{C}$ & 0.64 & 0.65 & 0.62 & 0.60 & 0.60 \\
& $40{ }^{\circ} \mathrm{C}$ & 0.66 & 0.65 & 0.63 & 0.62 & 0.62 \\
& $20^{\circ} \mathrm{C}$ & 0.60 & 0.59 & 0.58 & 0.56 & 0.56 \\
& $25{ }^{\circ} \mathrm{C}$ & 0.61 & 0.60 & 0.59 & 0.57 & 0.58 \\
& $30{ }^{\circ} \mathrm{C}$ & 0.62 & 0.62 & 0.61 & 0.60 & 0.59 \\
& $35^{\circ} \mathrm{C}$ & 0.64 & 0.63 & 0.62 & 0.62 & 0.61 \\
& $40{ }^{\circ} \mathrm{C}$ & 0.65 & 0.64 & 0.64 & 0.62 & 0.62 \\
\hline
\end{tabular}

Nevertheless, the existence of the dispersant and surfactant improves the suspension stability of the metal oxide nanoparticles in deionized water, thereby guiding more dispersion. The trend of the thermal conductivities over concentrations was the reverse of the trend of viscosity as shown in Fig. 8, implying that a rise in viscosity may lower the thermal conductivity of the metal oxide nanofluids. The dispersibility of the metal oxide nanofluids dropped with the increase in viscosity, which stalled the coagulation of the metal oxide nanoparticles in the deionized water over a long period because of the repulsive forces smaller than the attractive forces. The flow feature of a solid-liquid suspension depended on the hydrodynamic force acting on the surface of the solid particles. Fig. 8 reveals that the viscosity of the metal oxide nanofluids increased with an increase in the concentration resulting from the increase in attractive forces among a large number of metal oxide nanoparticles. The reason was that the addition of the dispersant disturbed the surface charges of the metal oxide nanoparticles, and further reduced their surface tension [17, 18].

Table 3 presents the changes in absorbance over four weeks for the metal oxide nanofluids at different concentrations. The absorbance value is an important index to discuss the suspendability of the metal oxide nanofluids. The larger the absorbance value, the more light is blocked by the metal oxide nanoparticles when passing through the sample. While detecting the absorbance, the sample fluid should not be shaken violently and need to be static for a long term to avoid measurement errors. The experiment measured absorbance at $350 \mathrm{~nm}$, $400 \mathrm{~nm}$, and $450 \mathrm{~nm}$ wavelengths. On the first day, higher concentrations gave larger absorbance values because the metal oxide nanopowders were more uniformly suspended all over the nanofluids and impeded more light. The absorbance value progressively lowered in the subsequent days because the metal oxide nanoparticles in the nanofluids slowly aggregated and the grain size increased with time causing the light to cross over more easily. In the fourth week, there was an increase in absorbance, although, it decreased slightly at $400 \mathrm{~nm}$ and $450 \mathrm{~nm}$. Therefore, it is improper to compare the absorbance at $350 \mathrm{~nm}$ with the metal oxide nanofluids at other concentrations.

For the 2 wt. $\% \mathrm{Al}_{2} \mathrm{O}_{3}$ nanofluids, the absorbance did not decrease with time at $350 \mathrm{~nm}$. There was no obvious variation in absorbance for the $2 \mathrm{wt} . \%$ $\mathrm{Al}_{2} \mathrm{O}_{3}$ nanofluid, whereas that for the $3 \mathrm{wt} . \%$ to 


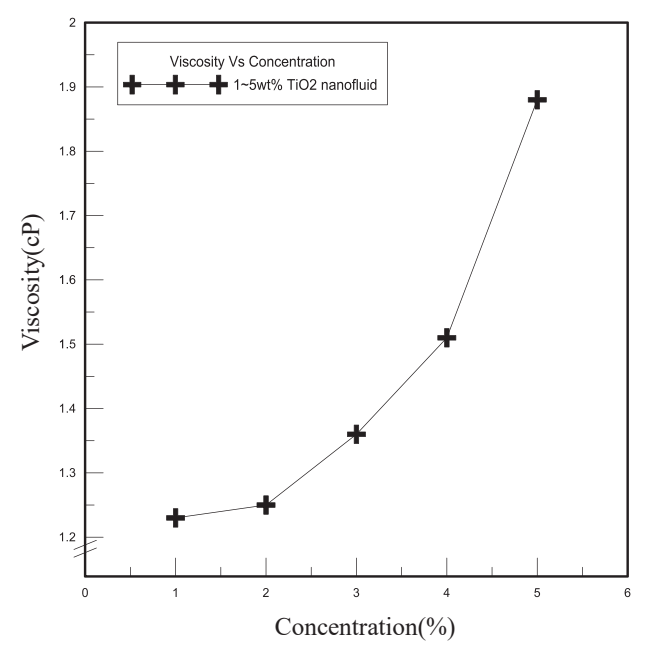

(a) $\mathrm{TiO}_{2}$

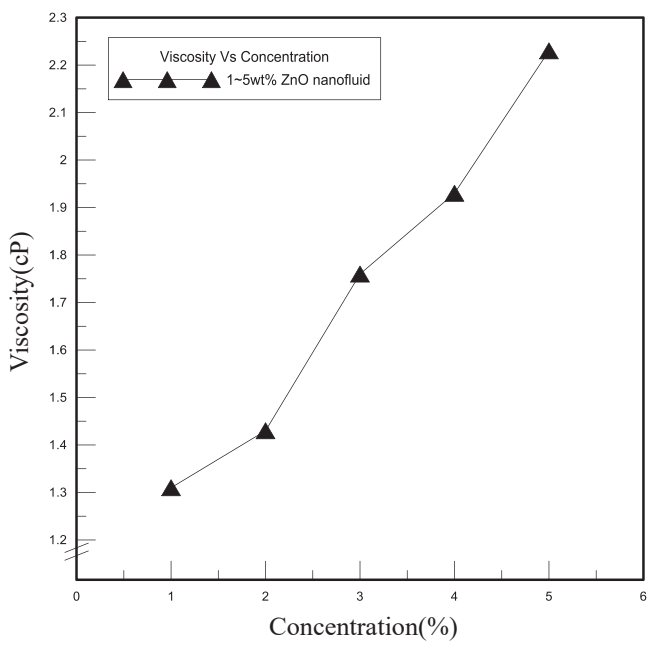

(b) $\mathrm{ZnO}$

Fig. 8. The viscosity of the metal oxide nanofluids.

5 wt. $\%$ nanofluids lowered slightly at $400 \mathrm{~nm}$. Among these concentrations, the $\mathrm{Al}_{2} \mathrm{O}_{3}$ nanofluid with 2 wt.\% had the highest absorbance values, indicating that the $2 \mathrm{wt} . \% \mathrm{Al}_{2} \mathrm{O}_{3}$ nanofluid was the best in terms of absorbance. The decrease in the absorbance of the $\mathrm{TiO}_{2}$ nanofluid at 1 wt. $\%$ was more significant at $400 \mathrm{~nm}$. Therefore, the larger $\mathrm{TiO}_{2}$ nanoparticles agglomeration phenomenon caused more serious precipitation. The precipitation of $\mathrm{TiO}_{2}$ nanoparticles seemed to slow down with a small difference between 2 wt. $\%$ and 5 wt. \%. For the $\mathrm{ZnO}$ nanofluid, the absorbance value of $1 \mathrm{wt} . \%$ to $5 \mathrm{wt} . \%$ reduced with time at $400 \mathrm{~nm}$. The decrease in the absorbance value of the $1 \mathrm{wt} . \%$ to $3 \mathrm{wt} . \% \mathrm{ZnO}$ nanofluids in 1-28 days was small while that of $4 \mathrm{wt} . \%$ to $5 \mathrm{wt} . \%$ decreased greatly.

The current and power densities were defined as the current and power generated per unit area of the battery tank, which also considers the influences of temperature and concentration of the metal oxide nanofluids. The area of each electrode under the liquid surface was about $1151.50 \mathrm{~mm}^{2}$. There were both positive and negative electrodes in the battery tank, therefore, the total reaction area was about $2303 \mathrm{~mm}^{2}$. The current and power densities were used to assess the power generation efficiency of the battery tank. Fig. 9 presents the power generation of metal oxide nanofluids. For the $\mathrm{TiO}_{2}$ nanofluid, it can be seen that the effect of an increase in concentration on the magnitude of power density is not large; as the temperature increased, the increase in power density was about $30 \%, 21 \%, 12 \%, 9 \%$, and $10 \%$. For the $\mathrm{ZnO}$ nanofluid, the effect of concentration on power density exhibited a decreasing trend with the increase in temperature The increase in power density was $20 \%, 14 \%, 17 \%, 7 \%$, and 14 , indicating that the concentration has little effect on the overall power density. As the concentration of the metal oxide nanofluids increased, the power density tended to increase. After the addition of the surfactant, the metal oxide nanofluid reacted with the metal oxide nanoparticles, and a small amount of electrolyte was generated to increase the electrical energy. The oxidation-reduction reaction rate of the battery tank was accelerated, thereby generating more electrical energy. Thus, the increase in ratio in power density decreased with an increase in temperature.

According to the above-mentioned results, 2 wt. $\%$ $\mathrm{TiO}_{2}, 1$ wt. $\% \mathrm{ZnO}$, and 2 wt. $\% \mathrm{Al}_{2} \mathrm{O}_{3}$ nanofluids were contrasted with each other to assess for better thermophysical properties. Fig. 10 shows the thermal conductivities of the metal oxide nanofluids with different nanopowders. The thermal conductivity of 1 wt.\% $\mathrm{ZnO}$ nanofluid was higher than $0.6 \mathrm{~W} /(\mathrm{m} \cdot \mathrm{K})$ at $20^{\circ} \mathrm{C}$. When the temperature was raised to $40{ }^{\circ} \mathrm{C}$, the $2 \mathrm{wt} . \% \mathrm{TiO}_{2}$ and $1 \mathrm{wt} . \% \mathrm{ZnO}$ nanofluids were $0.65 \mathrm{~W} /(\mathrm{m} \cdot \mathrm{K})$. The overall thermal conductivity of the $2 \mathrm{wt} . \% \mathrm{TiO}_{2}$ nanofluid was better between $25{ }^{\circ} \mathrm{C}$ and $40{ }^{\circ} \mathrm{C}$ except for a slight decline in thermal conductivity at $20^{\circ} \mathrm{C}$. Fig. 11 presents the average nanoparticle sizes of the metal oxide nanofluids with different nanopowders. The trend charts clearly show smaller average sizes of the $2 \mathrm{wt} . \% \mathrm{TiO}_{2}$ nanofluid. The agglomeration increase of nanoparticle sizes was respectively $19 \mathrm{~nm}$ of the 2 wt. $\% \mathrm{TiO}_{2}$ nanofluid, $59 \mathrm{~nm}$ of the $1 \mathrm{wt} . \% \mathrm{ZnO}$ nanofluid, and $36 \mathrm{~nm}$ of the $2 \mathrm{wt} . \% \mathrm{Al}_{2} \mathrm{O}_{3}$ nanofluid 
Table 3. Absorbance of metal oxide nanofluids at different concentrations.

\begin{tabular}{|c|c|c|c|c|c|c|c|}
\hline \multicolumn{3}{|l|}{ Wavelength (nm) } & \multirow{2}{*}{$\begin{array}{l}1 \mathrm{wt} . \% \\
2.26\end{array}$} & \multirow{2}{*}{$\begin{array}{l}2 \mathrm{wt} . \% \\
2.37\end{array}$} & \multirow{2}{*}{$\frac{3 w t . \%}{2.42}$} & \multirow{2}{*}{$\frac{4 w t . \%}{2.45}$} & \multirow{2}{*}{$\begin{array}{l}5 w t . \% \\
2.49\end{array}$} \\
\hline $\mathrm{Al}_{2} \mathrm{O}_{3}$ nanofluids & Day 1 & 350 & & & & & \\
\hline & & 400 & 2.33 & 2.48 & 2.45 & 2.51 & 2.53 \\
\hline & & 450 & 2.36 & 2.51 & 2.58 & 2.63 & 2.66 \\
\hline & Week 1 & 350 & 2.19 & 2.17 & 2.24 & 2.29 & 2.31 \\
\hline & & 400 & 2.22 & 2.44 & 2.49 & 2.53 & 2.57 \\
\hline & & 450 & 2.25 & 2.51 & 2.58 & 2.63 & 2.65 \\
\hline & Week 2 & 350 & 2.02 & 2.16 & 2.22 & 2.30 & 2.35 \\
\hline & & 400 & 2.18 & 2.44 & 2.48 & 2.49 & 2.55 \\
\hline & & 450 & 2.20 & 2.50 & 2.53 & 2.58 & 2.61 \\
\hline & Week 3 & 350 & 1.70 & 2.29 & 2.26 & 2.31 & 2.39 \\
\hline & & 400 & 1.63 & 2.43 & 2.34 & 2.39 & 2.42 \\
\hline & & 450 & 1.73 & 2.45 & 2.49 & 2.47 & 2.52 \\
\hline & Week 4 & 350 & 1.69 & 2.27 & 2.27 & 2.31 & 2.41 \\
\hline & & 400 & 1.62 & 2.41 & 2.34 & 2.34 & 2.44 \\
\hline & & 450 & 1.71 & 2.30 & 2.47 & 2.48 & 2.53 \\
\hline \multirow[t]{15}{*}{$\mathrm{TiO}_{2}$ nanofluids } & Day 1 & 350 & 1.93 & 1.96 & 1.85 & 1.82 & 1.80 \\
\hline & & 400 & 2.36 & 2.37 & 2.31 & 2.23 & 2.20 \\
\hline & & 450 & 2.40 & 2.41 & 2.40 & 2.26 & 2.18 \\
\hline & Week 1 & 350 & 1.90 & 1.91 & 1.81 & 1.76 & 1.73 \\
\hline & & 400 & 2.31 & 2.30 & 2.24 & 2.12 & 2.13 \\
\hline & & 450 & 2.38 & 2.36 & 2.35 & 2.22 & 2.12 \\
\hline & Week 2 & 350 & 1.87 & 1.86 & 1.81 & 1.70 & 1.69 \\
\hline & & 400 & 2.29 & 2.26 & 2.17 & 2.10 & 2.08 \\
\hline & & 450 & 2.33 & 2.31 & 2.30 & 2.17 & 2.09 \\
\hline & Week 3 & 350 & 1.81 & 1.82 & 1.73 & 1.67 & 1.64 \\
\hline & & 400 & 2.13 & 2.12 & 2.11 & 2.01 & 1.99 \\
\hline & & 450 & 2.30 & 2.29 & 2.27 & 2.09 & 2.05 \\
\hline & Week 4 & 350 & 1.80 & 1.80 & 1.69 & 1.61 & 1.59 \\
\hline & & 400 & 2.07 & 2.08 & 2.02 & 1.93 & 1.87 \\
\hline & & 450 & 2.26 & 2.26 & 2.24 & 2.06 & 2.02 \\
\hline \multirow[t]{15}{*}{ ZnO nanofluids } & Day 1 & 350 & 2.11 & 2.19 & 2.25 & 2.28 & 2.30 \\
\hline & & 400 & 2.39 & 2.41 & 2.48 & 2.52 & 2.56 \\
\hline & & 450 & 2.51 & 2.58 & 2.54 & 2.49 & 2.55 \\
\hline & Week 1 & 350 & 2.03 & 2.14 & 2.21 & 2.26 & 2.27 \\
\hline & & 400 & 2.34 & 2.35 & 2.36 & 2.42 & 2.39 \\
\hline & & 450 & 2.43 & 2.45 & 2.51 & 2.36 & 2.43 \\
\hline & Week 2 & 350 & 1.99 & 2.04 & 2.13 & 2.17 & 2.19 \\
\hline & & 400 & 2.20 & 2.33 & 2.31 & 2.37 & 2.32 \\
\hline & & 450 & 2.30 & 2.38 & 2.36 & 2.32 & 2.34 \\
\hline & Week 3 & 350 & 1.87 & 1.99 & 1.99 & 2.03 & 2.09 \\
\hline & & 400 & 2.12 & 2.20 & 2.20 & 2.22 & 2.26 \\
\hline & & 450 & 2.15 & 2.26 & 2.28 & 2.28 & 2.29 \\
\hline & Week 4 & 350 & 1.76 & 1.95 & 1.98 & 2.01 & 2.03 \\
\hline & & 400 & 2.07 & 2.15 & 2.17 & 2.19 & 2.20 \\
\hline & & 450 & 2.07 & 2.17 & 2.21 & 2.19 & 2.16 \\
\hline
\end{tabular}

during these 28 days. From the performance test, alumina and zinc oxide nanoparticle sizes aggregation lead to two obvious inferences. First, the surfactants and dispersion technology used in the present study had a better dispersion effect on the $\mathrm{TiO}_{2}$ particles, and second, was that the nanoparticle sizes of zinc oxide and aluminum oxide were larger during the preparation of nanoparticles resulting in less effective of dispersal of nanoparticles.

Under the influences of time, the precipitation of nanoparticles can be discussed in terms of the changes in the absorbance values. Particle precipitation was affected by factors such as nanoparticle sizes, material specific gravity, nanoparticle agglomerations, and surfactant and dispersion technology. Fig. 12 demonstrates the trend graphs of the absorbance of the metal oxide nanofluids at $400 \mathrm{~nm}$ wavelength. The suspension of $2 \mathrm{wt} \% \mathrm{TiO}_{2}$ nanofluid was better in the period of 1-28 days, with a decrease in absorbance of 0.26 . The corresponding decrease in absorbance of the $1 \mathrm{wt} . \% \mathrm{ZnO}$ nanofluid was 0.29 and that of the $2 \mathrm{wt} . \% \mathrm{Al}_{2} \mathrm{O}_{3}$ nanofluid was 0.28. Fig. 13 displays the power densities of the metal oxide nanofluids with different nanopowders. $\mathrm{TiO}_{2}, \mathrm{ZnO}$, and $\mathrm{Al}_{2} \mathrm{O}_{3}$ nanofluids were added to the battery tank. The output powers of the battery tank 


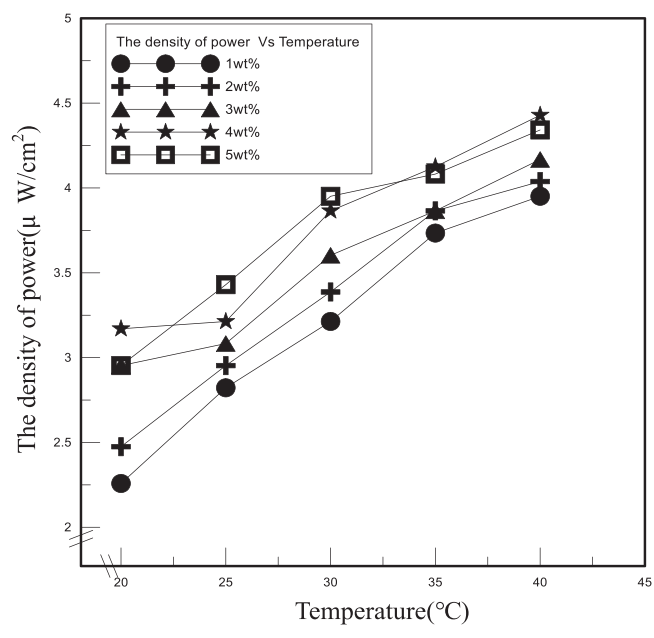

(a) $\mathrm{TiO}_{2}$

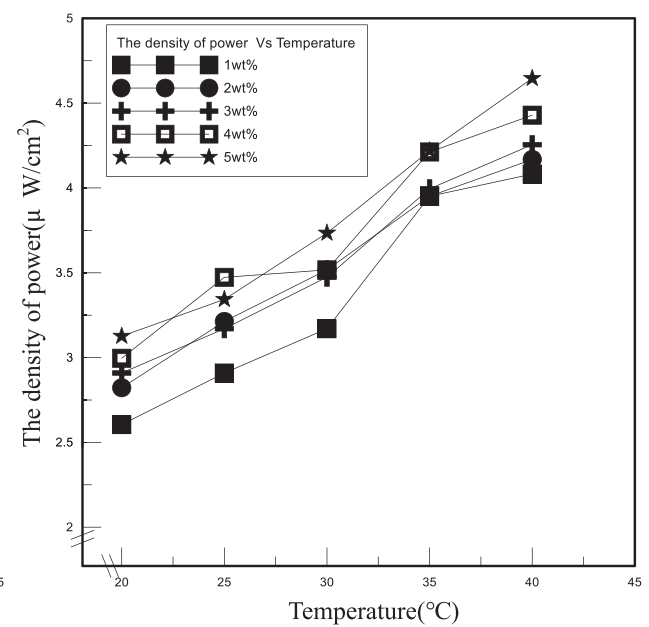

(b) $\mathrm{ZnO}$

Fig. 9. Power generations of the metal oxide nanofluids.

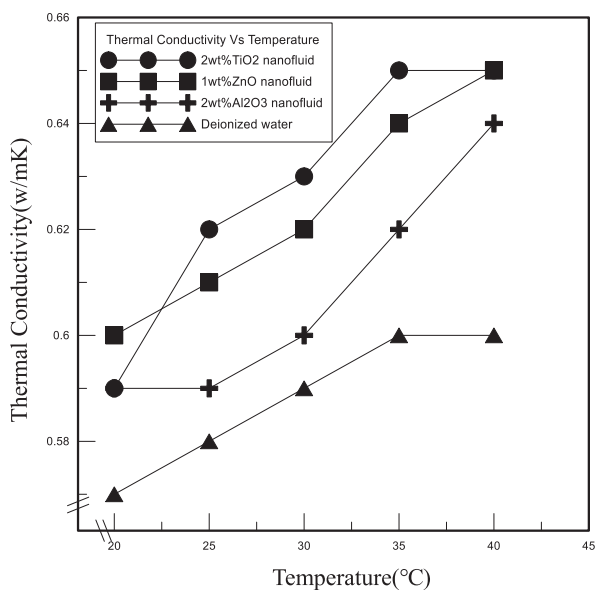

Fig. 10. Thermal conductivities of the metal oxide nanofluids.

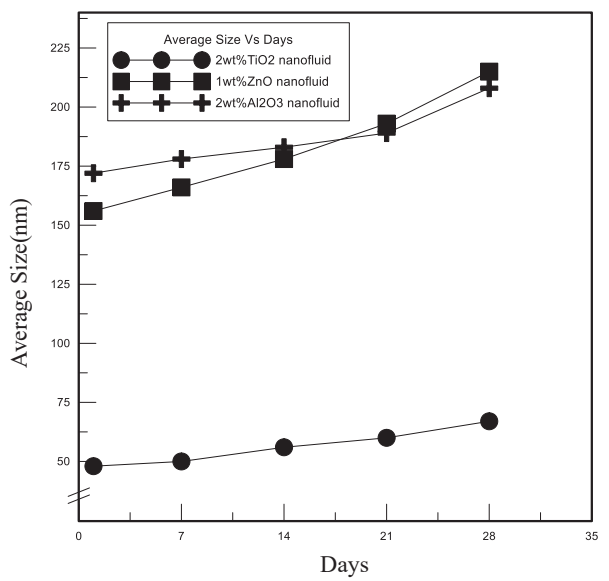

Fig. 11. Average sizes of the metal oxide nanofluids.

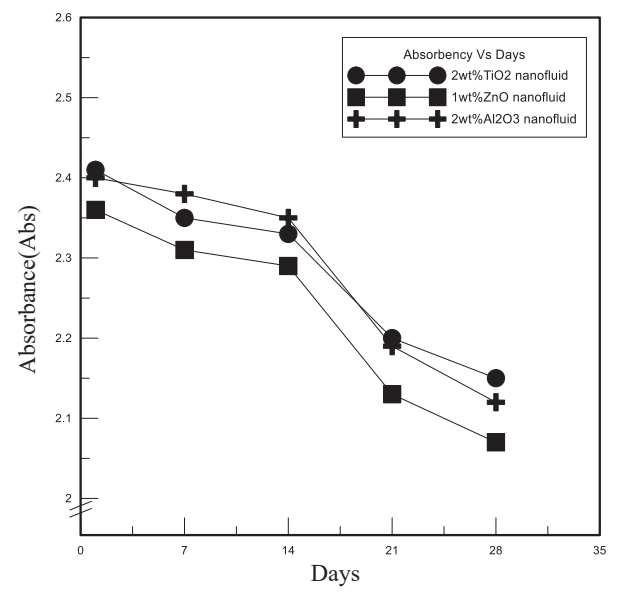

Fig. 12. Absorbance values of the metal oxide nanofluids.

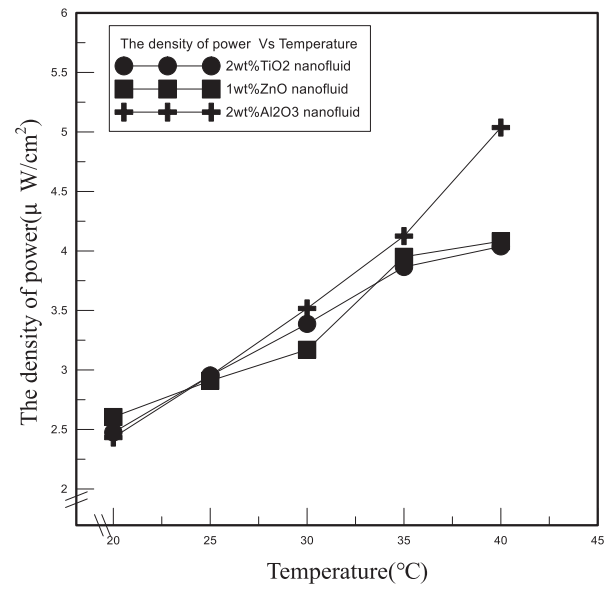

Fig. 13. Power densities of the metal oxide nanofluids. 
were detected with different metal oxide nanofluids and expressed as the power density. As the fluid temperature increased, there was a concurrent increase in the output power of the battery tank with different metal oxide nanofluids. The output powers of the $2 \mathrm{wt} . \% \mathrm{TiO}_{2}$ nanofluid, 1 wt. $\% \mathrm{ZnO}$ nanofluid, and $2 \mathrm{wt} . \% \mathrm{Al}_{2} \mathrm{O}_{3}$ nanofluid increased by $68 \%, 57 \%$, and $107 \%$, respectively, with an increase from $20{ }^{\circ} \mathrm{C}$ to $40{ }^{\circ} \mathrm{C}$ of fluid temperature. The overall output powers of $\mathrm{ZnO}$ and $\mathrm{TiO}_{2}$ were not much and low, while the overall output power of 2 wt. $\% \quad \mathrm{Al}_{2} \mathrm{O}_{3}$ nanofluid was higher.

\section{Conclusion}

In the present study, these metal oxide nanofluids were prepared to adjust the weight-percent concentration of the nanopowders and the surfactants at the same time employing the microemulsion ultrasonic dispersion technology. The best suspension stability of the alumina, $\mathrm{TiO}_{2}$, and $\mathrm{ZnO}$ nanofluids were obtained at $2.0 \mathrm{wt} . \%, 2.0 \mathrm{wt.} \%$, and $1.0 \mathrm{wt.} \%$, respectively, through four weeks. The viscosity of metal oxide nanofluids was between 1.0 and $3.0 \mathrm{cP}$ with negative dispersibility, and their thermal conductivities and the power generations were raised with an increase in temperature. Finally, the $\mathrm{TiO}_{2}$ nanofluid had better thermophysical properties and suspension stability, $\mathrm{Al}_{2} \mathrm{O}_{3}$ nanofluid had better electrical properties, and $\mathrm{TiO}_{2}$ nanofluid the best the overall thermoelectric properties among these three in the thermoelectric generation experiments. The present synthesis method is suitable for fabricating the metal oxide nanofluids at a temperature between $20{ }^{\circ} \mathrm{C}$ and $40{ }^{\circ} \mathrm{C}$ and a concentration of $1 \mathrm{wt} . \%$ to $5 \mathrm{wt} . \%$.

\section{Declaration of competing interest}

There is no conflict of interest.

\section{Nomenclature}

$\begin{array}{ll}\mathrm{A} & \text { Area, } \mathrm{m}^{2} \\ \mathrm{C} & \text { Specific heat, } \mathrm{kJ} / \mathrm{kg}^{\circ} \mathrm{C} \\ \mathrm{K} & \text { Thermal conductivity, } \mathrm{W} / \mathrm{m}^{\circ} \mathrm{C} \\ \mathrm{Q} & \text { Heat transfer rate, } \mathrm{W} \\ \mathrm{T} & \text { Temperature, }{ }^{\circ} \mathrm{C} \\ \mathrm{W} & \text { Weight percent concentration, } \% \\ \mathrm{Abs} & \text { Absorbance }\end{array}$

\begin{tabular}{ll}
\multicolumn{2}{c}{ Subscripts } \\
$\mathrm{p}$ & Nanoparticle \\
$\mathrm{bf}$ & Base fluid \\
$\mathrm{nf}$ & Nanofluid
\end{tabular}

\author{
Greek \\ $\mu \quad$ Viscosity, $\mathrm{m}^{2} / \mathrm{s}$ \\ $\rho \quad$ Density, $\mathrm{kg} / \mathrm{m}^{3}$
}

\section{References}

1 Maxwell JC. Electricity and magnetism, 2. New York: Dover; 1954.

2 Rezlescu N, Rezlescu E. Dielectric properties of copper containing ferrites. Physica status solidi (a) 1974;23(2):575-82.

3 Ramezanizadeh M, Nazari MA, Ahmadi MH, Açõkkalp E. Application of nanofluids in thermosyphons: A review. J Mol Liquids 2018;272:395-402.

4 Saville DA, Bellini T, Degiorgio V, Mantegazza F. An extended Maxwell-Wagner theory for the electric birefringence of charged colloids. J Chem Phys 2000;113(16):6974-83.

5 Li LZ, Tu XQ, Wang R, Peng L. Structural and magnetic properties of Cr-substituted NiZnCo ferrite nanopowders. J Magnetism Magnetic Mater 2015;381:328-31.

6 Manikandan AP, Monilan S, Shaabari NJ, Mathew A. Review on applications of metal and metal oxide nanoparticle in heat and mass transfer studies. Heat Transfer 2020;7(1).

7 Yazdanifard F, Ameri M, Ebrahimnia-Bajestan E. Performance of nanofluid-based photovoltaic/thermal systems: A review. Renew Sustain Energy Rev 2017;76:323-52.

8 Pordanjani AH, Aghakhani S, Afrand M, Mahmoudi B, Mahian O, Wongwises S. An updated review on application of nanofluids in heat exchangers for saving energy. Energy Conversion Manag 2019;198:111886.

9 Bhattad A, Sarkar J, Ghosh P. Improving the performance of refrigeration systems by using nanofluids: a comprehensive review. Renewable Sustain Energy Rev 2018;82:3656-69.

10 Shi L, Hu Y, He Y. Magnetocontrollable convective heat transfer of nanofluid through a straight tube. Appl Thermal Eng 2019;162:114220.

11 Wiriyasart S, Hommalee C, Sirikasemsuk S, Prurapark R, Naphon P. Thermal management system with nanofluids for electric vehicle battery cooling modules. Case Stud Thermal Eng 2020:100583.

12 Singh RP, Sharma K, Mausam K. Dispersion and stability of metal oxide nanoparticles in aqueous suspension: A review. Mater Today: Proc 2020;26:2021-5.

13 Azmi WH, Zainon SNM, Hamid KA, Mamat R. A review on thermo-physical properties and heat transfer applications of single and hybrid metal oxide nanofluids. J Mech Eng Sci 2019; 13(2):5182-211.

14 Drzazga M, Lemanowicz M, Dzido G, Gierczycki A. Preparation of metal oxide-water nanofluids by two-step method. Inż. Ap. Chem 2012;51(5):213-5.

15 Lin CY, Wang JC, Chen TC. Analysis of suspension and heat transfer characteristics of $\mathrm{Al} 2 \mathrm{O} 3$ nanofluids prepared through ultrasonic vibration. Appl Energy 2011;88(12):4527-33.

16 Wang JC, Lin CY, Chen TC. Thermal performance of a vapor chamber-based plate of high-power light-emitting diodes filled with Al2O3 nanofluid. J Nanosci Nanotechnol 2013;13(4): 2871-8.

17 Wang RT, Wang JC. Intelligent dimensional and thermal performance analysis of $\mathrm{Al} 2 \mathrm{O} 3$ nanofluid. Energy Convers Manag 2017;138:686-97.

18 Yen PH, Wang JC. Power generation and electric charge density with temperature effect of alumina nanofluids using dimensional analysis. Energy Convers Manag 2019;186: 546-55.

19 Wang RT, Wang JC. Alumina nanofluids as electrolytes comparisons to various neutral aqueous solutions inside battery. J Mech 2016;32(3):369-79.

20 Cacua K, Murshed SS, Pabón E, Buitrago R. Dispersion and thermal conductivity of $\mathrm{TiO} 2 /$ water nanofluid. J Therm Anal Calorim 2020;140(1):109-14. 
21 Moldoveanu GM, Minea AA, Huminic G, Huminic A. Al 2 O 3/TiO 2 hybrid nanofluids therm;al conductivity. J Therm Anal Calorim 2019;137(2):583-92.

22 Wang X, Yan X, Gao N, Chen G. Prediction of Thermal Conductivity of Various Nanofluids with Ethylene Glycol using Artificial Neural Network. J Therm Sci 2019:1-9.

23 Moradi A, Zareh M, Afrand M, Khayat M. Effects of temperature and volume concentration on thermal conductivity of TiO2-MWCNTs (70-30)/EG-water hybrid nano-fluid. Powder Technol 2020;362:578-85.

24 Yang L, Ji W, Huang JN, Xu G. An updated review on the influential parameters on thermal conductivity of nano-fluids. J Mol Liquids 2019:111780.

25 Gan YY, Ong HC, Ling TC, Zulkifli NWM, Wang CT, Yang YC. Thermal conductivity optimization and entropy generation analysis of titanium dioxide nanofluid in evacuated tube solar collector. Appl Therm Eng 2018;145:155-64.
26 Nadooshan AA. An experimental correlation approach for predicting thermal conductivity of water-EG based nanofluids of zinc oxide. Physica E: Low-dimensional Syst Nanostruct 2017;87:15-9.

27 Wang JC. Novel green illumination energy for LED with ocean battery materials. Int J Mater Product Technol 2012;44(3-4): 187-200.

28 Wang JC, Chiang WC. Researches on thermo-electric properties of seawater and $\mathrm{Al} 2 \mathrm{O} 3$ nanofluids. Applied mechanics and materials, 394. Trans Tech Publications Ltd; 2013. p. 14-9.

29 Wang JC. LED with Ocean Battery. Advanced Materials Research, 378. Trans Tech Publications Ltd; 2012. p. 646-9.

30 Wang, J. C., Wang, J. C., \& Chen, Y. C. (2017). Thermoelectric device. U.S. Patent Application No 15/626,400, 2017. https:// patents.google.com/patent/US20170373326A1/en. 